\author{
WIKTOR ŻOCHOWSKI \\ Uniwersytet Mikołaja Kopernika w Toruniu \\ wiktorzochowski@wp.pl
}

ORCID 0000-0002-6304-2991

\title{
Pomoc publiczna dla przedsiębiorców przed oraz w okresie trwania pandemii COVID-19
}

\author{
Public aid for entrepreneurs before and during the COVID-19 pandemic
}

Streszczenie. Zagadnienie pomocy publicznej w 2020 roku nabrało jeszcze większego znaczenia niż miało to miejsce dotychczas. W Polsce jednym ze skutków pandemii wirusa SARS-CoV-2 był lockdown, czyli zakaz swobodnego poruszania się obywateli powiązany z różnorodnymi nakazami, jak np. nakazem zasłaniania ust i nosa w miejscach publicznych. Efektem działań państwa było zamrożenie gospodarki oraz widmo kryzysu gospodarczego. Autor artykułu w swojej pracy zamierza podjąc się oceny działań instytucji państwowych w trakcie pandemii oraz przeanalizować historię i rozwój pojęcia pomocy publicznej w Polsce zarówno przed regulacjami wprowadzonymi na mocy Układu Europejskiego jak i po wstąpieniu do Unii Europejskiej.

\begin{abstract}
The issue of state aid in modern times has become even more important than ever. In Poland a virus pandemic caused lockdown, which is prohibition of free movement of citizens linked with other orders, for example the order to cover mouth and nose in public places. Effect of the state action was freezing the economy what could be beginning of economic crisis. Author of the article intends to assess action taken by Polish government in virus pandemic and analyse the history and development of the concept of state aid in Poland, both before introduction european regulations to Polish law and after joining European Union.
\end{abstract}

Słowa klucozwe: pomoc publiczna; Unia Europejska; COVID-19; pandemia; działalność gospodarcza.

Key words: state aid; European Union; COVID-19; pandemic; business activity.

\section{Wstęp}

W czasach, gdy świat stanął w obliczu kryzysu spowodowanego koronawirusem, pomoc publiczna, stała się nieocenionym narzędziem, umożliwiającym osobom prowadzącym działalność gospodarczą jej dalszy rozwój, a w sytuacjach kryzysowych będącym nierzadko jedynym instrumentem chroniącym przedsiębiorstwa przed nieuchronną upadłością spowodowaną brakiem płynności finansowej. Sama instytucja pomocy publicznej powstała na 
długo przed kryzysem, jest jednak stosunkowo nowym instrumentem w polskim porządku prawnym. Dopiero Układ Europejski z 1991 r., na mocy którego Polska zobowiązała się do dostosowania prawa krajowego do prawa wspólnotowego ${ }^{1}$, spowodował w naszym porządku prawnym uregulowanie dopuszczalności pomocy publicznej, wraz $\mathrm{z}$ odpowiednimi przepisami proceduralnymi z zakresu nadzorowania pomocy publicznej. ${ }^{2}$ Układ Europejski z uwagi na wprowadzanie podobnych regulacji, zastąpił umowę o wspólnym handlu oraz współpracy handlowej i gospodarczej z 19 września 1989 r. zawartą między Polską Rzeczpospolitą Ludową a Europejską Wspólnotą Gospodarczą. ${ }^{3}$ Wszedł on w życie ostatecznie dopiero 1 lutego 1994 roku, gdyż jego zawarcie wymagało ratyfikacji. W celu przyspieszenia realizacji jego postanowień zawarto Umowę Przejściową zapewniającą, że niektóre postanowienia Układu będą obowiązywały w polskim porządku prawnym już od 1 marca 1992 roku. Należały do nich m.in. postanowienia dotyczące konkurencji. Wobec powyższego możemy dojść do konkluzji, iż zagadnienie pomocy publicznej w Polsce jest silnie związane z procedurą i zobowiązaniami przedakcesyjnymi Polski do UE.

Definicja pomocy publicznej wykształciła się na gruncie art. 107 ust. 1 Traktatu o funkcjonowaniu Unii Europejskiej, w którym wymieniono, jakie działania państwa mogą być traktowane jako pomoc publiczna. Ustanowiono także zakaz takich działań państwa, które zakłócają lub grożą zakłóceniem konkurencji poprzez sprzyjanie niektórym przedsiębiorstwom lub produkcji niektórych towarów, jeśli jest to niezgodne z rynkiem wewnętrznym w zakresie, w jakim wpływa to na wymianę handlową między państwami członkowskimi ${ }^{4}$.

Metodyka pracy polega na opracowaniu zagadnienia pomocy publicznej i jej praktycznego zastosowania poprzez obserwację i analizę działań państwa przed pandemią oraz $\mathrm{w}$ jej trakcie. Praca będzie traktowała owo zagadnienie z perspektywy jego historycznego rozwoju, uwzględniając jego wpływ na działalność gospodarczą. Autor używa metody formalno-dogmatycznej.

\footnotetext{
1 Układ Europejski ustanawiający stowarzyszenie między Rzecząpospolitą Polską, z jednej strony, a Wspólnotami Europejskimi i ich Państwami Członkowskimi, z drugiej strony, sporządzony w Brukseli dnia 16 grudnia 1991 r., Dz. U z 1994 r. Nr 11, poz. 38.

2 I. Postuła, A. Werner, Prawo pomocy publicznej, Warszawa, 2008, LEX.

${ }^{3}$ Umowa między Polską Rzeczpospolitą Ludową a Europejską Wspólnotą Gospodarczą w sprawie handlu oraz współpracy handlowej z dnia 16 grudnia 1991 r., Dz. U. z 1990 r. Nr. 38, poz. 214.

${ }^{4}$ Traktat o funkcjonowaniu Unii Europejskiej z dnia 25 marca 1957 r., Dz. U. z 2004 r. Nr 90, poz. 864(2).
} 


\section{Powstanie i rozwój instytucji pomocy publicznej}

Pojęcie pomocy publicznej funkcjonowało nieformalnie w naszej gospodarce od dawna. Przed wprowadzeniem regulacji prawnych $\mathrm{w}$ tej dziedzinie była ona jednak traktowana jedynie jako instrument ekonomiczny nieuregulowany prawnie, polegający na chociażby wspomaganiu przedsiębiorców w postaci dotacji, ulg czy zwolnień podatkowych. Działania te jednakże nie odnosiły się do reguł dopuszczalności działalności publicznej, ponieważ takie jeszcze nie istniały. ${ }^{5}$

Przed przystąpieniem do Unii Europejskiej w polskim porządku prawnym musiały zostać wprowadzone zmiany dostosowujące prawo krajowe do wymagań wspólnotowego porządku prawnego. Odkąd Polska jest członkiem Unii Europejskiej częścią jej porządku prawnego są reguły dopuszczalności pomocy publicznej, mające swe podstawy w Traktacie o funkcjonowaniu Unii Europejskiej. Od tego czasu obowiązuje również ustawa ${ }^{6}$ regulująca jednak wyłącznie kwestie wstępnej kontroli pomocy publicznej. Miano najważniejszej z ustaw w tym zakresie wydaje się jednak przypadać ustawie o warunkach dopuszczalności i nadzorowaniu pomocy publicznej dla przedsiębiorców z 2000r. ${ }^{7}$ oraz tak samo zatytułowana ustawa z 2002 r. ${ }^{8}$ Były one wynikiem deklaracji strony polskiej w zobowiązaniach przedakcesyjnych, w ramach których prawo polskie miało zostać dostosowane do acquis z dniem 31 grudnia 2001 roku, co zostało wyrażone $w$ polskich stanowiskach negocjacyjnych. ${ }^{9}$ Następstwem reform prawnych będących kontynuacją przystosowywania prawa polskiego do norm europejskich była nowelizacja ustawy o ochronie konkurencji i konsumentów ${ }^{10}$ zobowiązująca Prezesa Urzędu Ochrony Konkurencji i Konsumentów do współpracy z organami unijnymi.

\section{Rodzaje i formy pomocy publiczne w Polsce - zastosowanie regulacji unijnych}

Dotychczas wypracowano wiele rodzajów pomocy publicznej. Jednymi z pierwszych były programy pomocowe oraz pomoc indywidualna. Zgodnie $\mathrm{z}$ rozporządzeniem Rady (WE) nr 659/1999 z dnia 22 marca 1999 r. ustanawiającym szczegółowe zasady stosowania art. 93 Traktatu WE, programem pomocowym może być wyłącznie akt generalny

\footnotetext{
${ }^{5}$ I. Postuła, A. Werner, Prawo op.cit., Warszawa 2008, Lex.

6 Ustawa z dnia 30 kwietnia 2004 r. o postępowaniu w sprawach dotyczących pomocy publicznej, Dz.U. z 2004 r. Nr 123 poz. 1291.

${ }^{7}$ Ustawa z dnia 30 czerwca 2000r. o warunkach dopuszczalności i nadzorowaniu pomocy publicznej dla przedsiębiorców, Dz. U. z 2000 r. Nr 60, poz. 704.

${ }^{8}$ Ustawa z dnia 27 lipca 2002 r. o warunkach dopuszczalności i nadzorowaniu pomocy publicznej dla przedsiębiorców, Dz. U. z 2002 r. Nr 141 poz. 1177.

${ }_{9}^{9}$ P. Pełka, M. Stasiak, Pomoc publiczna dla przedsiębiorców w Unii Europejskiej, Warszawa 2002, s. 12.

${ }^{10}$ Ustawa z dnia 16 lutego 2007 r. o ochronie konkurencji i konsumentów, Dz. U. z 2007 roku Nr 50 poz. 331.
} 
i abstrakcyjny, należący do norm prawa powszechnie obowiązującego ${ }^{11}$. Programy te określają dokładnie krąg beneficjentów, formę udzielanego wsparcia, jego przeznaczenie, organy udzielające, maksymalną wielkość pomocy i czas obowiązywania programu. Konieczne jest ich notyfikowanie Komisji Europejskiej. Pomocą indywidualną natomiast jest wsparcie, które nie zostało przyznane na podstawie programu pomocowego. Jest ona kierowana co do zasady do konkretnego beneficjenta. ${ }^{12}$ Specyficznym rodzajem wsparcia jest pomoc istniejąca - taka, która istniała już w chwili wejścia w życie przepisów dotyczących badania zgodności wsparcia publicznego ze wspólnym rynkiem, jednak ze względu na brak uregulowań w tej dziedzinie podczas jej udzielania nie była wówczas uznawana za pomoc państwa. Jest to kategoria pomocy o szczególnym znaczeniu dla państw nowo przyjętych do Unii Europejskiej, wiążąca się z zasadą poszanowania praw słusznie nabytych przez przedsiębiorców. W Polsce za pomoc istniejącą zostały uznane m.in. zwolnienia podatkowe dla spółek motoryzacyjnych działających na terenie specjalnych stref ekonomicznych, co wiąże się z sui generis obowiązkami sprawozdawczymi. ${ }^{13}$ Są nią także dotacje dla indywidualnie oznaczonych podmiotów. Pomoc indywidualna na restrukturyzację jest szczególnym jej rodzajem, gdyż jednym z warunków jej udzielenia jest opracowanie przez przedsiębiorcę planu restrukturyzacyjnego. $Z$ tego tytułu przedsiębiorca otrzymuje wiele instrumentów wspierających jego działalność, jak np. umorzenia zadłużenia publicznoprawnego od różnych organów, dotacje na restrukturyzację zatrudnienia, gwarancje spłaty kredytów obrotowych, pożyczki inwestycyjne. ${ }^{14}$ Rekompensata z tytułu świadczenia usług w ogólnym interesie gospodarczym i pomoc w ramach wyłączeń grupowych są to dwa przypadki świadczenia pomocy publicznej dla bardzo ograniczonej grupy podmiotów. W trakcie kryzysu wywołanego koronawirusem państwo podjęło kroki mające na celu wsparcie małych, średnich oraz dużych przedsiębiorstw ${ }^{15}$ przy wykorzystaniu pomocy indywidualnej lub programowej. Dla małych oraz średnich przedsiębiorców udostępniono wsparcie w formie pożyczki, która może być wykorzystana na pokrycie kosztów działalności gospodarczej, z wyłączeniem finansowania nabycia (przejęcia) innego przedsiębiorcy oraz

\footnotetext{
11 Rozporządzenie Rady (WE) NR 659/1999 z dnia 22 marca 1999 r. ustanawiające szczegółowe zasady stosowania art. 93 Traktatu WE, Dz.U. L 83 z 27.3.1999.

${ }^{12}$ K. Gałązka, Pomoc publiczna dla przedsiębiorców, Urząd Ochrony Konkurencji i Konsumentów, Warszawa 2012, s. 25-26.

13 Ibidem. s. 26-27.

14 Urząd Ochrony Konkurencji i Konsumentów, Programy pomocowe $i$ pomoc indywidualna, https://www.uokik.gov.pl/programy_pomocowe_i_pomoc_indywidualna2.php (dostęp 04 sierpnia 2020).

${ }^{15}$ Ustawa z dnia 6 marca 2018r., Prawo przedsiębiorców, Dz. U. 2018 poz. 650, art. 4 i art. 7.
} 
przedterminową spłatę kredytów do maksymalnej wysokości 25 proc. wartości pożyczki. ${ }^{16}$ Natomiast przedsiębiorcy zatrudniający co najmniej 250 pracowników, o obrotach powyżej $50 \mathrm{mln}$ euro lub sumie bilansowej przekraczającej 43 miliony euro mogą ubiegać się o wsparcie $\mathrm{w}$ formie pożyczek lub obligacji na poprawę płynności na okres 2 lat z opcją przedłużenia o rok o wartości do miliarda złotych, pożyczek preferencyjnych na okres trzech lat, częściowo bezzwrotnych i uzależnionych od straty finansowej oraz utrzymania zatrudnienia, o wartości do $750 \mathrm{mln}$ zł i instrumentów kapitałowych (udziałów lub akcji) finansujących inwestycje o wartości do miliarda złotych. ${ }^{17}$

Jednym z głównych mechanizmów realizacji polityki spójności Unii Europejskiej na terenie poszczególnych państw członkowskich jest pomoc regionalna, udzielana w ramach regionalnych programów operacyjnych. Podstawowymi rodzajami wsparcia regionalnego są pomoc inwestycyjna, wsparcie dla nowo założonych małych przedsiębiorstw oraz w ograniczonym zakresie pomoc operacyjna. Co do zasady zabronione jest wsparcie mające na celu zmniejszenie bieżących wydatków przedsiębiorcy przyznawane jedynie w związku z bardzo poważnymi opóźnieniami danego regionu. Stosuje się je w przypadku gdy pomoc inwestycyjna może okazać się nieskuteczna przy wyrównywaniu różnic gospodarczych. Głównym czynnikiem warunkującym pomoc w rozwoju gospodarczemu regionów jest przelicznik produktu krajowego brutto (PKB) na mieszkańca, który musi być niższy niż 75 procent średniej unijnej. ${ }^{18}$ Zagadnieniem wchodzącym w skład pomocy regionalnej jest jej intensywność na poszczególnych terenach, zgodnie z progami intensywności wynikającymi z wytycznych, zależnymi od wysokości PKB na jednego mieszkańca. Ten rodzaj pomocy jest skonstruowany w taki sposób, aby wspomóc rozwój najmniej uprzywilejowanych regionów przez wspieranie inwestycji i tworzenie nowych miejsc pracy. Promuje ona dywersyfikację działalności gospodarczej przedsiębiorstw znajdujących się na tych regionach, zwłaszcza przez zachęcanie różnych koncernów do otwierania tam nowych zakładów. W Polsce pomoc ta opiera się przede wszystkim na dofinansowaniach bądź dotacjach, a ich intensywność (inaczej rozmiar) zależy od wcześniej wymienionych czynników. Można z niej skorzystać na terenie całego kraju, jednak jej poziom jest zróżnicowany w zależności od województwa,

\footnotetext{
${ }^{16} 100$ mld dla firm. Kto może skorzystać i na jakich warunkach, https://www.forbes.pl/gospodarka/koronawirusw-polsce-warunki-udzielania-pomocy-finansowej-dla-firm-w-polsce/ysnf063 (dostęp 04 sierpnia 2020).

${ }^{17}$ Ibidem.

${ }^{18}$ K. Gałązka, Pomoc op.cit, s. 36.
} 
na którym osoba ubiegająca się o pomoc prowadzi działalność gospodarczą. ${ }^{19} \mathrm{~W}$ okresie pandemii wywołanej wirusem SARS-COV-2 ten rodzaj pomocy nadal funkcjonuje.

Kolejnym wsparciem preferowanym przez Unię Europejską jest pomoc sektorowa oraz pomoc horyzontalna. Pierwsza $\mathrm{z}$ nich jest wsparciem przyznawanym pod względem przynależności do danej branży, gdyż jest udzielana wyłącznie przedsiębiorcom z konkretnego sektora gospodarczego (np. z sektora transportu), jak również w sektorach wrażliwych jak np. sektor hutnictwa żelaza i stali, przemysł stoczniowy, górnictwo węgla. ${ }^{20}$ Jej założeniem jest rozwiązywanie problemów długofalowych, nakierowanie na przyszłość i udzielanie specyficznego wsparcia, które ma prowadzić do obniżenia zdolności produkcyjnych i produkcji we wrażliwych sektorach, ponieważ jest to korzystne dla przywrócenia konkurencyjności na rynku unijnym. Szczególny charakter tego wsparcia wynika z kapitochłonnego charakteru inwestycji dokonywanych $\mathrm{w}$ tych obszarach oraz permanentnych trudności związanych m.in. z funkcjonowaniem takiej działalności. Pomoc sektorowa stanowi potencjalnie największe zagrożenie dla konkurencji gdyż jej często doraźny charakter wpływa bezpośrednio na unijną wymianę handlową. Wymienione powyżej czynniki sprawiają, że proces wdrażania pomocy sektorowej jest wysoce skomplikowany. Pomoc horyzontalna natomiast jest zagadnieniem dużo prostszym w realizacji, a zarazem jest najbardziej preferowaną przez Komisję Europejską formą wsparcia ze względu na korzyści, jakie przynosi gospodarce. Działanie pomocy horyzontalnej ukierunkowane jest na pewne określone cele, a jej udzielenie nie jest zależne od regionu, w którym beneficjent prowadzi działalność. $^{21}$ Jej główne zadanie polega na rozwiązaniu określonego problemu z jakim boryka się przedsiębiorca poprzez udzielenie mu wsparcia finansowego. ${ }^{22}$ Jest wsparciem ukierunkowanym na ogólne cele związane z jej unowocześnianiem i wspieraniem wzrostu gospodarczego, który jest niezależny od regionu czy sektora (w odróżnieniu od pomocy regionalnej czy sektorowej). Jej celem jest realizacja europejskiej polityki spójności i nakierunkowanie na badania, rozwój i innowację oraz ochronę środowiska, szkolenia i zatrudnienie. W Polsce realizowane są założenia pomocy horyzontalnej w każdym z wymienionych wcześniej aspektów. Rodzajem pomocy wynikającym z pomocy horyzontalnej jest pomoc na ratowanie i restrukturyzację. Obok pomocy sektorowej jest to jedno z najbardziej kontrowersyjnych zagadnień, gdyż stanowi największe zagrożenie dla

\footnotetext{
${ }^{19}$ P. Kaczmarek, K. Wiśniewski, Pomoc regionalna - zasady wspierania inwestycji gospodarczych w najmniej rozwiniętych regionach, https://www.rp.pl (dostęp 04 sierpnia 2020).

${ }^{20}$ Pomoc publiczna, Urząd Ochrony Konkurencji i Konsumentów, www.uokik.gov.p1/pomoc_publiczna_2.php (dostęp 30 lipca 2020).

${ }^{21}$ Biuletyn Informacji Publicznej, www.bip.krakow.pl (dostęp 30 lipca 2020).

${ }^{22}$ Urząd Ochrony Konkurencji i Konsumentów, www.uokik.gov.pl (dostęp 30 lipca 2020).
} 
wspólnego rynku, bowiem za jego pośrednictwem wspiera się przedsiębiorców nieefektywnych, którzy bez pomocy państwa najprawdopodobniej nie byliby się w stanie na nim utrzymać. Ze względu na to, wsparcie udzielane takim przedsiębiorcom podlega bezwzględnemu obowiązkowi notyfikacji Komisji Europejskiej i jest obwarowane szczególnymi, restrykcyjnymi warunkami jego dopuszczalności. Może być ona przyznawana co do zasady jedynie jako wsparcie indywidualne, a celem tej pomocy jest zachowanie płynności finansowej przedsiębiorstwa na czas konieczny do opracowania planu restrukturyzacji. Jest to $\mathrm{w}$ założeniu pomoc czasowa i zwrotna. Musi być ograniczona do niezbędnego minimum i trwać maksymalnie sześć miesięcy, a po upływie tego czasu przedsiębiorca ma obowiązek przedstawić Komisji Europejskiej dowód spłaty pożyczki oraz plan likwidacji lub spójny plan restrukturyzacji zawierający informacje o badaniu rynku, prognozach na przyszłość, dotyczący całej struktury przedsiębiorstwa. Co istotne, ten rodzaj pomocy rządzi się zasadą ,pierwszy i ostatni raz”, gdyż jej wielokrotne przyznawanie jedynie pogłębiałoby negatywne konsekwencje i powodowało problemy pozostałych uczestników rynku. Nie jest to jednak zasada bezwzględna, gdyż po upływie 10 lat od ostatniej pomocy na ratowanie i restrukturyzację przedsiębiorca może ponownie wystąpić o jej udzielenie. ${ }^{23}$ Zgodnie z dotychczasowymi ramami prawnymi ustalonymi przez UE, w czasie pandemii COVID-19 państwo wciąż może zapewniać wsparcie lub ułatwiać rozwój niektórych działań gospodarczych lub niektórych regionów gospodarczych, o ile nie zmienia warunków

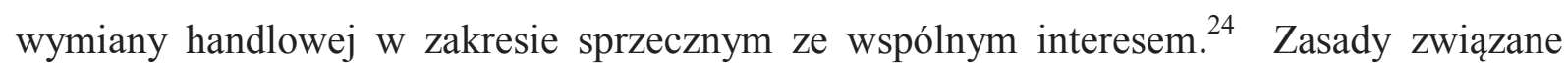
z przyznawaniem pomocy sektorowej również nie uległy zmianie, natomiast $\mathrm{w}$ obecnych czasach działanie państwa skupia się przede wszystkim na wsparciu przedsiębiorców dotkniętych skutkami pandemii, a zatem inwestycji w branżach związanych z konkretnymi sektorami gospodarki jest stosunkowo mniej niż przed pandemią.

Rodzajem pomocy publicznej zasługującym na uwagę jest także ekwiwalent dotacyjny. Jest to dość skomplikowany rodzaj pomocy publicznej, który wymaga odpowiedniego przelicznika. Wiąże się z dwoma czynnikami: formą pomocy oraz opodatkowaniem pomocy. Ulga związana z opodatkowaniem może być przedstawiona na dwa sposoby: jako ekwiwalent dotacji brutto (EDB) lub netto (EDN). EDB to kwota pomocy, którą otrzymałby beneficjent lub podmiot ubiegający się o pomoc, gdyby uzyskał wsparcie w formie dotacji, bez uwzględnienia opodatkowania podatkiem dochodowym. Natomiast

\footnotetext{
${ }^{23}$ K. Gałązka, Pomoc op. cit., s. 27-42.

${ }^{24}$ Koronawirus $w$ UE - tymczasowe ramy prawne umożliwia udzielanie przedsiębiorcom dodatkowej pomocy publicznej w związu z COVID-19, www.parp.gov.pl (dostęp 04 sierpnia 2020).
} 
EDN odzwierciedla wielkość wsparcia z uwzględnieniem wartości tego podatku. ${ }^{25}$ Pomoc publiczna udzielana jest w formach, w których dla obliczenia rzeczywistej korzyści, jaką otrzymał przedsiębiorca należy przeliczyć pomoc na ekwiwalent dotacyjny, czyli kwotę, którą otrzymałby przedsiębiorca, gdyby formą pomocy była dotacja. Tak obliczona kwota pomocy została nazwana EDB. Do przykładowych form jej pomocy należy zaliczyć kredyty preferencyjne lub gwarancje kredytowe. EDB jest stosowany przede wszystkim w celu sprawdzenia, czy wartość udzielanej pomocy nie przekracza progu de minimis. ${ }^{26}$ De minimis jest również rodzajem pomocy publicznej, nie mającej jednak konkretnego celu, lecz wyodrębnionej kwotowo, co przyczynia się do odciążenia zarówno Komisji Europejskiej, jak i administracji państw członkowskich, od konieczności zajmowania się każdym przypadkiem planowanej pomocy. Jej głównym celem jest zapewnienie równowagi między uproszczeniem przepisów, a minimalnym zakłóceniem konkurencji na rynku. Ma ona nieznaczny wpływ na konkurencję i wymianę handlową między państwami członkowskimi, lecz mimo tego istnieje obowiązek prowadzenia przez państwa członkowskie ewidencji takiego wsparcia. Z kolei po stronie Komisji, możliwość zażądania wszelkich informacji, jakie uzna za niezbędne do oceny ex post jej zgodności z prawem unijnym. ${ }^{27} \mathrm{~W}$ Polsce wprowadzono system monitorujący pomoc de minimis oparty na każdorazowym pisemnym powiadamianiu beneficjentów pomocy de minimis o takim jej statusie. Uzyskanie takiej pomocy przez wnioskodawcę związane jest ze szczegółową procedurą, podczas której ów podmiot jest zobowiązany do przedstawienia podmiotowi udzielającemu pomocy różnorodnych informacji, przede wszystkim poprzez wypełnianie odpowiednich formularzy. Swoistą namiastką centralnego rejestru pomocy de minimis w Polsce można uznać udostępnioną od 2016 r. na stronie UOKiK bazę danych o nazwie ${ }^{28}$ System Udostępniania Danych o Pomocy Publicznej (SUDOP), służący jako wyszukiwarka dla pomocy otrzymanej przez danego beneficjenta. ${ }^{29}$ $\mathrm{W}$ zakresie pomocy w rolnictwie i rybołówstwie funkcjonuje także wyszukiwarka on-line, która została udostępniona w ramach Systemu Rejestracji Pomocy Publicznej (SRPP) służącego do obsługi sprawozdań o udzielonej pomocy publicznej zgodnie z rozporządzeniem

\footnotetext{
25 Ekwiwalent dotacyjny brutto i netto, https:/www.gofin.pl/firma/17,2,122,125333, ekwiwalent-dotacyjnybrutto-i-netto.html (dostęp 30 lipca 2020).

${ }^{26}$ P. Pełka, M. Stasiak, Pomoc publiczna dla przedsiębiorców w Unii Europejskiej, Warszawa 2002 s. 41.

27 A. A. Ambroziak, K. P.-Wróbel, R. Zanc, Pomoc publiczna dla przedsiębiorców. Wybrane zagadnienia. Perspektywa podmiotu udzielającego pomocy $i$ jej beneficjenta $w$ Polsce, Wolters Kluwer, Warszawa 2020, s. 130-131.

${ }^{28}$ Ibidem, s. 142-144

${ }^{29}$ SUDOP (System Udostępniania Danych o Pomocy Publicznej) - wyszukiwarka pomocy otrzymanej przez danego Beneficjenta, Psz.praca.gov.pl (dostęp 30 lipca 2020) .
} 
Rady Ministrów z dnia 3 kwietnia 2007 r. w sprawie sprawozdań o udzielonej pomocy publicznej w rolnictwie lub rybołówstwie oraz informacji o nieudzieleniu pomocy. ${ }^{30}$

Obecnie wydaje się, iż w dobie kryzysu spowodowanego wybuchem pandemii, podstawową formą pomocy dla mikro czy małych przedsiębiorców jest opisana powyżej pomoc de minimis. Regulacje dotyczące tego rodzaju pomocy znalazły się w tzw. tarczach antykryzysowych, które zapewniają między innymi zwolnienie ze składek ZUS. ${ }^{31}$ Obejmują one również gwarancje de minimis, stanowiące zabezpieczenie spłaty kredytu obrotowego lub inwestycyjnego dla mikro, małego lub średniego przedsiębiorcy, czego przykładem jest zwiększenie zakresu gwarancji do 80\% kwoty kredytu zaciąganego w banku komercyjnym czy wydłużenie okresu gwarancji do 39 miesięcy dla kredytu obrotowego. ${ }^{32} \mathrm{~W}$ skutek gwałtownego przyrostu osób zarażonych na COVID-19 od września 2020 r. i utrzymywania się wysokiego progu zachorowań , rząd planuje wprowadzić kolejne środki będące pomocą de minimis. Obecnie do Senatu trafiła przyjęta przez Sejm ustawa nazywana nową tarczą antykryzysową (tzw. Tarcza 6.0) ${ }^{33}$, w której znajdują się chociażby przepisy przewidujące pomoc w postaci kolejnych zwolnień z płacenia składek ZUS, nowe świadczenia postojowe czy także możliwość uzyskania dotacji w wysokości 5 tysięcy złotych $\mathrm{w}$ formie tzw. bezzwrotnej pożyczki. ${ }^{34}$

\section{Sprawdzian dla pomocy publicznej w okresie obostrzeń spowodowanych wirusem}

\section{SARS-CoV-2}

Wybuch pandemii na przełomie zimy i wiosny 2020 r. wywarł ogromny wpływ na funkcjonowanie całego społeczeństwa. Jednymi z najbardziej problematycznych pytań zadawanych w jej trakcie są te dotyczące pomocy publicznej dla przedsiębiorców w okresie pandemii. Musieli oni w dynamicznym tempie dostosowywać swoje zakłady do coraz to nowszych regulacji prawnych. W związku z dynamicznym rozwojem pandemii w Polsce, nastąpiło zamknięcie większości działalności gospodarczych na skutek lockdownu. Dla wielu osób, będących zarówno pracodawcami jak i pracownikami, oznaczało to czasowe odcięcie

\footnotetext{
30 A. Domański, System rejestracji pomocy publicznej, instrukcja użytkowania. Margie - oprogramowanie dla administracji, Warszawa 2016.

31 Ustawa z dnia 17 września 2020 r. o zmianie ustawy o szczególnych rozwiązaniach związanych z zapobieganiem, przeciwdziałaniem i zwalczaniem COVID-19, innych chorób zakaźnych oraz wywołanych nimi sytuacji kryzysowych oraz niektórych innych ustaw, Dz. U. z 2020 roku, poz. 1639.

${ }^{32}$ Tarcza antykryzysowa. Pytania $i$ odpowiedzi, https://www.gov.pl/web/tarczaantykryzysowa/pytania-iodpowiedzi (dostęp: 26 listopada 2020).

33 Sprawozdanie Komisji Polityki Społecznej i Rodziny o poselskim projekcie ustawy o zmianie ustawy o szczególnych związanych z zapobieganiem przeciwdziałaniem i zwalczaniem COVID-19, innych chorób zakaźnych oraz wywołanych nimi sytuacji kryzysowych (druk sejmowy nr 709).

${ }^{34}$ Będa nowe dotacje dla firm. Rząd znów wyplaci bezzwrotnie 5 tys. zt., https://zus.pox.pl/zus/koronawirusnowe-dotacje-dla-firm-rzad-znow-wyplaci-bezzwrotne-5-tys-zl.htm (dostęp 26 listopada 2020).
} 
ich od środków utrzymania. Osobom prowadzącym działalność gospodarczą groziło bankructwo, a pracownikom - utrata pracy. Państwo po analizie sytuacji na rynku pracy rozpoczęło wdrażanie nowych ustaw, modyfikowanie prawa pracy oraz uchwalanie tzw. tarcz antykryzysowych, zawierających w sobie pewne przywileje i udogodnienia wobec poszczególnych grup podmiotów na rynku pracy.

Szereg zmian prawa pracy $\mathrm{w}$ celu zapobieżenia negatywnym skutkom zmian gospodarczych wynikających z pandemii COVID-19 wprowadzała tzw. Tarcza antykryzysowa 3.0. Przewidziany w niej szereg szczególnych regulacji dotyczył w znacznej mierze uproszczenia czynności stricte biurokratycznych (zmiana warunków wykonywania pracy przez cudzoziemców, brak konieczności systematycznego potwierdzania określonych umiejętności i kwalifikacji ze względu na czasowe wyłączenie tego wymogu) ${ }^{35}$, ale również różnorodnych świadczeń socjalnych. W tym miejscu warto nadmienić dodatkowy zasiłek opiekuńczy (wyłącznie dla osób wykonujących określony zawód ${ }^{36}$ ), prawo do pełnego wynagrodzenia za pracę w okresie kwarantanny wraz z dodatkami o charakterze stałym wyłącznie dla wyznaczonych funkcjonariuszy oraz osób zatrudnionych w jednostkach organizacyjnych pomocy społecznej. Najbardziej wyczekiwaną przez przedsiębiorców zmianą było jednakże zwolnienie z obowiązku płacenia składek na ubezpieczenie społeczne, zdrowotne oraz na Fundusz Pracy, Emerytur Pomostowych, Solidarnowościowy i Fundusz Gwarantowanych Świadczeń Pracowniczych. ${ }^{37}$ Ze zwolnienia ze składek za okres od dnia 1 kwietnia 2020 r. do dnia 31 maja 2020 r. mogli skorzystać ci przedsiębiorcy, którzy w pierwszym miesiącu, za który wnioskowali o zwolnienie, osiągnęli przychody w kwocie przekraczającej dotychczas ustalony limit czyli 300\% prognozowanego przeciętnego miesięcznego wynagrodzenia brutto w gospodarce narodowej w 2020 r., pod warunkiem, że ich dochód w pierwszym miesiącu, za który jest składany wniosek o zwolnienie z opłacania składek nie przekroczył 7000 zł. Warunkiem skorzystania z prawa do ulgi jest prowadzenie działalności przed dniem 1 kwietnia $2020 \mathrm{r}^{38}$ Również przedsiębiorcy dopiero rozpoczynający swoją działalność mają możliwość zwolnienia ze składek na ubezpieczenia oraz Fundusze. Kolejnym ukłonem w stronę pracowników oraz pracodawców było zwiększenie kwoty wolnej od potrąceń komorniczych ${ }^{39}$ wynikających z sytuacji pracownika

\footnotetext{
${ }^{35}$ P. Zawadzka-Filipczyk, Tarcza antykryzysowa 3.0 - rozwiazania w zakresie prawa pracy, Lex.

${ }^{36}$ Ustawa $\mathrm{z}$ dnia 14 maja 2020r. o zmianie niektórych ustaw w zakresie działań osłonowych w związku z rozprzestrzenianiem się wirusa SARS-CoV-2, Dz. U. z 2020 roku, poz. 875, art. 73.

${ }^{37}$ Zwolnienie ze składek ZUS na 3 miesiace, www.gov.pl/web/gov/ zwolnienie-ze-skladek-ZUS-na-3-miesiace (dostęp 30 lipca 2020).

${ }^{38}$ Zob. P. Zawadzka-Filipczyk, Tarcza antykryzysowa, Lex (dostęp 23 lipca 2020).

${ }^{39}$ Ustawa z dnia 26 czerwca 1974 r. - Kodeks pracy (Dz. U. z 2019 r. poz. 1040, 1043 i 1495), art. 87.
} 
np. w celu uregulowania należności alimentacyjnych, długów, zaliczek pieniężnych

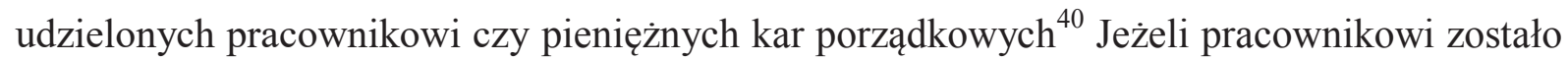
obniżone wynagrodzenie lub członek rodziny pracownika utracił źródło dochodu, kwoty wolne od potrąceń uległy zwiększeniu o $25 \%$ na każdego nieosiągającego dochodu członka rodziny, którego pracownik ma na utrzymaniu. ${ }^{41}$

W związku z przedłużającym się okresem trwania pandemii koronawirusa przyjęto rządowy projekt ustawy mający wprowadzić kolejne zmiany w celu ustabilizowania gospodarki. ${ }^{42}$ Ustawodawca wprowadził możliwości zgłoszenia przerwy w wykonywaniu działalności gospodarczej dla podatników opodatkowanych w formie karty podatkowej. Rozwiązanie to wciąż nie dawało jednak przedsiębiorcom ani pracownikom możliwości choćby ograniczonego powrotu do kontynuowania działalności gospodarczej, lecz zwolniło przedsiębiorców od kosztów związanych z zapłatą podatku dochodowego za okres nieprowadzenia działalności gospodarczej spowodowany wprowadzonym zakazem jej prowadzenia. W związku z powyższym podatek płacony w formie karty podatkowej uległ obniżeniu o 1/30 za każdy dzień w czasie obowiązywania zakazu prowadzenia działalności. Ponadto, w dalszym ciągu kontynuowano politykę zdalnego załatwiania spraw związanych z dokumentacją i formalnym funkcjonowaniem przedsiębiorstwa (eg. brak obowiązku zawiadomienia urzędu skarbowego o przerwie w działalności) ${ }^{43}$.

Zmiany prawne wprowadzone $\mathrm{w}$ tzw. Tarczy antykryzysowej $4.0^{44}$ nadały znaczne uprawnienia Prezesowi Urzędowi Ochrony Konkurencji i Konsumentów w zakresie przejmowania spółek lub nabywania znacznego pakietu akcji i udziałów w polskiej spółce przez podmiot spoza Unii Europejskiej, Europejskiego Obszaru Gospodarczego, Organizacji Współpracy Gospodarczej i Rozwoju. Przez „znaczny pakiet akcji/udziałów” ustawodawca przyjął próg 20\%. Głównym motywem wskazanego działania była ochrona polskich przedsiębiorstw przed „wrogim przejęciem”, czyli procesem uzyskania kontroli nad przedsiębiorstwem pomimo braku zgody dotychczasowego zarządu poprzez zakup

\footnotetext{
${ }^{40}$ Zespół ifirma.pl, Kwota wolna od potraceń a tarcza antykryzysowa 3.0, www.ifirma.pl news/kwota-wolna-odpotracen-a-tarcza-antykryzysowa-3-0.html (dostęp 30 lipca 2020).

${ }^{41}$ Ustawa $\mathrm{z}$ dnia 14 maja 2020r. o zmianie niektórych ustaw w zakresie działań osłonowych w związku z rozprzestrzenianiem się wirusa SARS-CoV-2, Dz. U. z 2020 roku, poz. 875, art. 5.

${ }^{42}$ Ustawa $\mathrm{z}$ dnia 19 czerwca 2020r. o dopłatach do oprocentowania kredytów bankowych udzielanych przedsiębiorcom dotkniętym skutkami COVID- 19 oraz o uproszczonym postępowaniu o zatwierdzenie układu W związku z wystąpieniem COVID-19, Dz.U. z 2020 roku poz. 1086.

${ }^{43}$ I. Kaczorowska, Redakcja, Tarcza 4.0 - przerwa $w$ działalności gospodarczej z powodu COVID-19, Lex (dostęp 23 lipca 2020).

${ }^{4}$ Ustawa z dnia 19 czerwca 2020 r. o dopłatach do oprocentowania kredytów bankowych udzielanych przedsiębiorcom dotkniętym skutkami COVID-19 oraz o uproszczonym postępowaniu o zatwierdzenie składu w związku z wystąpieniem COVID-10, Dz.U. z 2020 roku, poz. 1086.
} 
wystarczającej ilości aktywów spółki, które umożliwią pozyskanie przez nabywcę większościowego głosu na walnym zgromadzeniu akcjonariuszy ${ }^{45}$, na co $\mathrm{w}$ swoim komunikacie wskazywało Ministerstwo Rozwoju. ${ }^{46} \mathrm{O}$ tym, czy dane przejęcie jest wrogie, decyduje Prezes UOKiK. Kolejną formą pomocy dla osób prowadzących działalność gospodarczą są dopłaty do oprocentowania kredytów bankowych. Obecne czasy nazywane są „złotymi żniwami” dla banków, gdyż znaczna ilość przedsiębiorców z uwagi na niewydolność finansową zadłuża się w bankach, aby uniknąć bankructwa. Ustawodawca postanowił wprowadzić do porządku prawnego szereg przepisów regulujących sytuację, w których państwo dopłaca do oprocentowania przy zaciąganych kredytach. Tym samym możemy zauważyć, że objęci tymi regulacjami są wyłącznie przedsiębiorcy w rozumieniu ustawy - Prawo przedsiębiorców i podmioty prowadzące działalność w sektorze produkcji rolnej (rolnicy). Uregulowane są również typy kredytów, co do których przysługuje pomoc państwowa. Są to kredyty odnawialne i nieodnawialne, udzielane w złotych, w celu zapewnienia płynności finansowej, w szczególności krótkoterminowej i średnioterminowej, utraconej lub zagrożonej utratą w związku z konsekwencjami rozprzestrzeniania się COVID19. ${ }^{47}$ Nowa ustawa uprościła także postępowanie restrukturyzacyjne, doprecyzowała zasady wykonywania pracy zdalnej, wprowadziła możliwość wprowadzenia przestoju ekonomicznego i obniżonego wymiaru niezależnie od spadku obrotów, uzyskania dofinansowania z Funduszu Gwarantowanych Świadczeń Pracowniczych niezależnie od obniżenia wymiaru czasu czyli ilości zmniejszenia wymiaru pracy pracownikowi przez pracodawcę, jednostronnego udzielenia urlopu wypoczynkowego przez pracodawcę, obniżyła wysokość odpraw ustawowych, umożliwiła wypowiedzenie umowy o zakazie konkurencji przez pracodawcę, a także wprowadzanie zmian w czasie pracy niezależnie od spadku obrotów gospodarczych czy nawet doprecyzowanie warunków dofinansowania części kosztów wynagrodzeń pracowników przez starostę. Przy okazji wyliczenia zmian wprowadzonych w tzw. Tarczy antykryzysowej 4.0 warto wspomnieć, iż zostały wprowadzone również zmiany w prawie podatkowym, które uwzględniają pomoc dla przedsiębiorcy w konkretnych przypadkach.

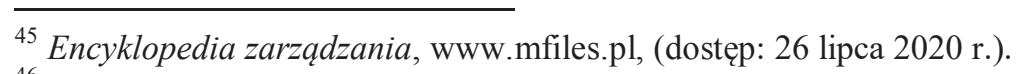

${ }^{46}$ MR: Obrona polskich firm, miejsc pracy, kredytobiorców i samorząów w kolejnej pakietowej ustawie, która złoży się na tarczę antykryzysowa (komunikat) (korekta), http://centrumprasowe.pap.pl (dostęp 5 sierpnia 2020)

47 Ustawa z dnia 19 czerwca 2020r. o dopłatach do oprocentowania kredytów bankowych udzielanych przedsiębiorcom dotkniętym skutkami COVID- 19 oraz o uproszczonym postępowaniu o zatwierdzenie układu w związku z wystąpieniem COVID-19, Dz.U. z 2020 roku, poz. 1086, art. 2.
} 


\section{Wnioski}

Stan pomocy publicznej w Polsce można podzielić na pewne okresy: okres przed wdrożeniem pierwszych regulacji wspólnotowych (przed 1992 r.), okres, w którym wprowadzane były regulacje unijne oraz ze względu na tematykę artykułu - okres pandemii koronawirusa w 2020 r. Wprowadzenie wielu programów europejskich do polskiej rzeczywistości umożliwiło znacznej ilości przedsiębiorców rozwój ich działalności, jej rozpoczęcie, czy nawet ochronę przed upadkiem, a liczne dotacje pochodzące od Unii Europejskiej spowodowały rozwój gospodarczy Polski. W początkowej fazie kryzysu wydawało się jednak, że państwo nie sprostało pokładanej w nim nadziei. Praktyką powszechną na całym świecie było odraczanie terminów zapłaty podatków bądź ich całkowite zniesienie na pewien czas, czasowa rezygnacja z podatku od towarów i usług (VAT) lub przełożenie terminów na jego uregulowanie, wiele ulg, zmniejszanie podatków czy stawek, przy czym w Polsce występowała stosunkowo mała skala tychże działań. Dla porównania, Australia zamierza przesunąć niektóre płatności podatków nawet do czterech miesięcy oraz zawiesić stosowanie odsetek za zwłokę i sankcji podatkowych, jeśli powstały one po 23 stycznia 2020 r., Stany Zjednoczone wydłużają terminy podatkowe podobnie jak Australia, a w Europie liczne udogodnienia wprowadza Szwecja, której rząd skrócił wymiar czasu pracy, ułatwił zawieszenie i odwieszenie prowadzenia działalności gospodarczej, a szwedzkie przedsiębiorstwa uzyskały możliwość odroczenia do dwóch miesięcy składek na ubezpieczenia zdrowotne i społeczne i zaliczek na podatek od dochodów pracowników. W celu zahamowania zachorowań na COVID-19 oraz zatrzymania rozprzestrzeniania się pandemii, Unia Europejska powołała zespół ds. szybkiego reagowania na koronawirusa, a Komisja Europejska koordynuje wspólną europejską reakcję na pandemię. Podjęte zostały działania mające wzmocnić sektor zdrowia publicznego, a momentem przełomowym było uchwalenie budżetu na lata 2021-2027, którego nazwą jest „Plan odbudowy dla Europy”, gdyż jego znaczną część pochłonęły środki na odbudowę gospodarek krajowych po koronawirusie. $^{48}$ Kryzys dotyka również jednostki samorządu terytorialnego. Sytuacja ta związana jest m.in. ze stratą dochodach z podatków dochodowych (CIT i PIT). Wszystkie te czynniki prowadzą do konkluzji, iż pomoc publiczna wspomagana w znacznej mierze przez programy unijne ma istotny wkład w rozwój działalności gospodarczej w Polsce, natomiast, jak wykazał początek kryzysu gospodarczego spowodowanego szerzeniem się wirusa SARSCoV-2, rząd nie jest $\mathrm{w}$ stanie zaspokoić potrzeb przedsiębiorców, wiele podmiotów

\footnotetext{
${ }^{48}$ Koronawirus - reakcja UE, https://ec.europa.eu/info/live-work-travel-eu/health/coronavirus-response_pl (dostęp: 30 lipca 2020 r.).
} 
gospodarczych upada i niewątpliwie upadnie w przyszłości. Jak wynika z danych GUS-u, od kwietnia do września bieżącego roku zamknięto 2055 firm gastronomicznych, ponad 4,3 tysiące przedsiębiorców zawiesiło działalność i szacuje się, że na koniec roku ta liczba wyniesie 7 tysięcy. ${ }^{49}$ Ponadto, dane udostępnione przez Główny Urząd Statystyczny wskazują także na fakt, iż bezrobocie w Polsce od wybuchu pandemii spowodowanej COVID-19 w ciągu 3 miesięcy wzrosło o 0,6 punktów procentowych. ${ }^{50}$ Następnym etapem w dobie kryzysu było trwające od maja 2020 roku odmrażanie gospodarki oraz wprowadzanie kolejnych tarcz antykryzysowych, czego efektem było zatrzymanie rosnącego bezrobocia. Wczesną jesienią 2020 roku nastąpił ponowny wybuch zachorowań na COVID-19 czego efektem było powtórne wprowadzenie obostrzeń oraz częściowy lockdown gospodarki. Część klubów fitness oraz siłowni, aby uniknąć ponownego zamknięcia po ogłoszeniu nowych obostrzeń przez rząd, ${ }^{51}$ stara się wykorzystywać luki w prawie celem dalszego funkcjonowania, doprowadzając do tak skrajnych sytuacji jak chociażby przekształcanie siłowni w kościół. ${ }^{52}$ Również branża gastronomiczna znajduje się w opłakanej sytuacji. Po wprowadzeniu zakazu przebywania w lokalach w październiku 2020 r., osoby działające w tej branży poza pomocą od rządu muszą przede wszystkim opierać się na zamówieniach na wynos od klientów. Z drugiej strony, wobec panującej sytuacji możemy zauważyć zjawisko wzmożonej mobilizacji wobec społeczeństwa, które stara się wspierać lokalnych przedsiębiorców. Jednakże to nie w gestii obywateli powinno znajdować się wspieranie, a wręcz ratowanie poszczególnych działów gospodarki, a biorąc pod uwagę powyższe można sformułować tezę w myśl której rząd, pomimo podejmowanych prób i wdrażania kolejnych regulacji prawnych, nie podołał w całości wymaganiom stawianym wobec niego w okresie trwania pandemii, czego dowodami są zarówno dane statystyczne prowadzone przez organy państwowe, jak również praktyka życia codziennego.

\footnotetext{
${ }^{49}$ Polska gastronomia $w$ dramatycznej sytuacji. „To dla nas kompletny szok” https://www.money.pl/gospodarka/polska-gastronomia-w-dramatycznej-sytuacji-to-dla-nas-kompletny-szok6567733686946496a.html

${ }^{50}$ Główny Urząd Statystyczny, Stopa bezrobocia rejestrowanego w latach 1990-2020 https://stat.gov.pl/obszarytematyczne/rynek-pracy/bezrobocie-rejestrowane/stopa-bezrobocia-rejestrowanego-w-latach-19902020,4,1.html, (dostęp: 25 listopada 2020 r.).

${ }^{51}$ www.prawo.pl, Rząd obiecuje szybkie otwarcie basenów $i$ siłowni https://www.prawo.pl/biznes/zamknieciesilowni-basenow-i-klubow-fitness-z-powodu-epidemii,503899.html (dostęp: 26 listopada 2020 r.).

${ }^{52}$ Polish express, Siłownia w Krakowie zamieniła się w „, Kościół Zdrowego Ciała”, aby uniknąć zamknięcia, https://www.polishexpress.co.uk/silownia-w-krakowie-zamienila-sie-w-kosciol-zdrowego-ciala-aby-uniknaczamkniecia (dostęp: 26 listopada 2020 r.).
} 


\title{
Bibliografia:
}

\author{
Akty normatywne \\ $\begin{array}{llllllll}\text { Traktat o funkcjonowaniu Unii Europejskiej } \mathrm{z} & \text { dnia } 25 & \text { marca } & 1957 & \text { r., }\end{array}$ \\ (Dz. U. z 2004 r. Nr 90, poz. 864(2)).
}

Ustawa z dnia 26 czerwca 1974 r. - Kodeks pracy (Dz. U. z 2019 r. poz. 1040, 1043 i 1495).

Układ Europejski ustanawiający stowarzyszenie między Rzeczpospolitą Polską, z jednej strony, a Wspólnotami Europejskimi i ich Państwami Członkowskimi, z drugiej strony, sporządzony w Brukseli dnia 16 grudnia 1991 r., Dz. U z 1994 r. Nr 11, poz. 38.

Rozporządzenie Rady (WE) NR 659/1999 z dnia 22 marca 1999 r. ustanawiające szczegółowe zasady stosowania art. 93 Traktatu WE, Dz.U. L 83 z 27.3.1999.

Ustawa z dnia 30 czerwca 2000 r. o warunkach dopuszczalności i nadzorowaniu pomocy publicznej dla przedsiębiorców, Dz. U. z 2000 r. Nr 60, poz. 704.

Ustawa z dnia 27 lipca 2002 r. o warunkach dopuszczalności i nadzorowaniu pomocy publicznej dla przedsiębiorców, Dz. U. 2002 r. Nr 141, poz. 1177.

Ustawa z dnia 30 października 2002 r. o pomocy publicznej dla przedsiębiorców o szczególnym znaczeniu dla rynku pracy, Dz. U. z 2002 r. Nr 213, poz. 1800.

Ustawa z dnia 30 kwietnia 2004 r. o postępowaniu w sprawach dotyczących pomocy publicznej, (Dz.U. 2004 r. Nr 123, poz. 1291).

Ustawa z dnia 16 lutego 2007 r. $\quad$ o ochronie konkurencji i konsumentów (Dz. U. 2007 r. Nr 50, poz. 331).

Ustawa z dnia 6 marca 2019 r. Prawo przedsiębiorców (Dz. U. z 2018 r. poz. 650).

Ustawa z dnia 14 maja 2020 r. o zmianie niektórych ustaw w zakresie działań osłonowych w związku z rozprzestrzenianiem się wirusa SARS-CoV-2 (Dz. U. 2020 r. poz. 875).

Ustawa z dnia 19 czerwca 2020 r. o dopłatach do oprocentowania kredytów bankowych udzielanych przedsiębiorcom dotkniętym skutkami COVID-19 oraz o uproszczonym postępowaniu o zatwierdzenie układu w związku z wystąpieniem COVID-19 (Dz.U. 2020 r. poz. 1086).

Ustawa z dnia 17 września 2020 r. o zmianie ustawy o szczególnych rozwiązaniach związanych z zapobieganiem, przeciwdziałaniem i zwalczaniem COVID-19, innych chorób zakaźnych oraz wywołanych nimi sytuacji kryzysowych oraz niektórych innych ustaw (Dz.U. z 2020 r. poz. 1639).

Sprawozdanie Komisji Polityki Społecznej i Rodziny o poselskim projekcie ustawy o zmianie ustawy o szczególnych związanych z zapobieganiem przeciwdziałaniem i zwalczaniem COVID-19, innych chorób zakaźnych oraz wywołanych nimi sytuacji kryzysowych (druk sejmowy nr 709).

\section{Literatura}

Ambroziak A. A, Pamuła-Wróbel K., Zenc R, Pomoc publiczna dla przedsiębiorców. Wybrane zagadnienia. Perspektywa podmiotu udzielajacego pomocy $i$ jej beneficjenta $w$ Polsce, Warszawa 2020.

Gałązka K., , Pomoc publiczna dla przedsiębiorców, Warszawa 2012.

Pełka P., Stasiak M., Pomoc publiczna dla przedsiębiorców w Unii Europejskiej, Warszawa 2002.

Postuła I., Werner A., Prawo pomocy publicznej, Warszawa 2008.

\section{Źródla internetowe}

Ministerstwo Nauki i Szkolnictwa Wyższego, Definicja pomocy publicznej, www.archiwum.nauka.gov.pl (dostęp: 30 lipca 2020 r.).

Zawadzka-Filipczyk P., Tarcza antykryzysowa 3.0 - rozwiazania $w$ zakresie prawa pracy, Lex (dostęp: 23 lipca 2020 r.).

Kaczorowska I., Redakcja, Tarcza 4.0 - przerwa w dziatalności gospodarczej z powodu COVID - 19, Lex (dostęp: 23 lipca 2020 r.).

Stefanik D., Kudłacz K. [w:] Encyklopedia zarzadzania, www.mfiles.pl, (dostęp: 26 lipca 2020 r.).

Szulc M., Zalewski Ł., Preferencje podatkowe $w$ dobie pandemii. Jak fiskus na świecie walczy $z$ koronawirusem, https://podatki.gazetaprawna.pl/artykuly/1460450,koronawirus-ulgi-podatkowe-dlafirm.html (dostęp: 27 lipca 2020 r.). 
Główny Urząd Statystyczny, Stopa bezrobocia rejestrowanego $w$ latach 1990-2020, https://stat.gov.pl/obszary-tematyczne/rynek-pracy/bezrobocie-rejestrowane/stopa-bezrobociarejestrowanego-w-latach-1990-2020,4,1.html, (dostęp: 27 lipca 2020 r.).

Pomoc publiczna, Urząd Ochrony Konkurencji $i$ Konsumentów, www.uokik.gov.pl/pomoc_publiczna_2.php (dostęp: 4 sierpnia 2020 r.).

Urząd Ochrony Konkurencji i Konsumentów, Programy pomocowe $i$ pomoc indywidualna, https://www.uokik.gov.pl/programy_pomocowe_i_pomoc_indywidualna2.php (dostęp: 4 sierpnia 2020 r.).

Ekwiwalent dotacyjny brutto $i$ netto, https://www.gofin.pl/firma/17,2,122,125333, ekwiwalentdotacyjny-brutto-i-netto.html (dostęp: 4 sierpnia 2020 r.).

SUDOP (System Udostepniania Danych o Pomocy Publicznej) - wyszukiwarka pomocy otrzymanej przez danego Beneficjenta, Psz.praca.gov.pl (dostęp: 30 lipca 2020 r.).

Domański A., System rejestracji pomocy publicznej, instrukcja użytkowania. Margie oprogramowanie dla administracji, Warszawa 2016.

Zwolnienie ze sktadek ZUS na 3 miesiace, www.gov.pl/web/gov/ zwolnienie-ze-skladek-ZUS-na-3miesiace (dostęp: 4 sierpnia 2020 r.).

100 mld dla firm. Kto może skorzystać $i$ na jakich warunkach, https://www.forbes.pl/gospodarka/koronawirus-w-polsce-warunki-udzielania-pomocy-finansowej-dlafirm-w-polsce/ysnf063 (dostęp: 4 sierpnia 2020 r.).

Koronawirus - reakcja UE, https:/ec.europa.eu/info/live-work-travel-eu/health/coronavirusresponse_pl (dostęp: 4 sierpnia 2020 r.).

Koronawirus $w$ UE - tymczasowe ramy prawne umożliwia udzielanie przedsiębiorcom dodatkowej pomocy publicznej w zwiazku z COVID-19, www.parp.gov.pl (dostęp: 4 sierpnia 2020 r.).

Rząd obiecuje szybkie otwarcie basenów i sitowni, https://www.prawo.pl/biznes/zamkniecie-silownibasenow-i-klubow-fitness-z-powodu-epidemii,503899.html (dostęp: 26 listopada 2020 r.).

Siłownia w Krakowie zamieniła się $w$ „Kościót Zdrowego Ciała”, aby uniknać zamknięcia, https://www.polishexpress.co.uk/silownia-w-krakowie-zamienila-sie-w-kosciol-zdrowego-ciala-abyuniknac-zamkniecia (dostęp: 26 listopada 2020 r.).

Tarcza antykryzysowa. Pytania i odpowiedzi, https://www.gov.pl/web/tarczaantykryzysowa/pytania-iodpowiedzi (dostęp: 26 listopada 2020 r.).

Będa nowe dotacje dla firm. Rząd znów wyptaci bezzwrotnie 5 tys. zt., https://zus.pox.pl/zus/koronawirus-nowe-dotacje-dla-firm-rzad-znow-wyplaci-bezzwrotne-5-tyszl.htm (dostęp: 26 listopada 2020 r.). 